\title{
Cahiliyenin Kültürel Kodları
}

\section{Şinasi GÜNDÜZ*}

\section{The Cultural Codes of Jahiliyyah}

Citation/C): Gündüz, Şinasi, (2016). The Cultural Codes of Jahiliyyah, Milel ve Nihal, 13 (1), 8-27.

Abstract: Jâhiliyyah, an important term of the Qur'an, is not a concept that is limited to the Arabic society of the period of revelation of the Qur'an. Rather, it is the expression of an understanding of life and a perspective on human being, and of a cultural structure that is mainly based on tradition, ancestral cult and hegemonic powers settled in social structure. On the basis of jâhiliyyah there exists an idea that the earthly power/powers instead of Allah's will and orders are accepted as the main reference of human life. This is, consequently, totally against the Islamic doctrine stressing that only God's will should be decisive on human thinking and life since Allah is the only ilâh, mainly the only supreme decisive power and authority. A perception that those who have the power are always right, that is dependent of the sacredness of social, political, economic and military power, is dominant in the social structures based on jâhiliyyah. It is a fact that this perception always causes injustice, oppression and persecution in the society.

Key Words: jâhiliyyah, tradition, status quo, cultural structure, power, authority, ancestral cult

Atıf/C: Gündüz, Şinasi, (2016). Cahiliyenin Kültürel Kodları, Milel ve Nihal, 13 (1), 8-27.

Öz: Kur'an'da kullanılan önemli bir terim olarak cahiliye, yalnızca Kur'an'ın indiği dönem Arap toplumuyla sınırlı olan bir kavram değildir. Cahiliye; gelenek, atalar kültü ve sosyal yapıda yerleşik hegemonyal güçlere dayalı bir hayat anlayışının, insana yönelik bir perspektifin ve bir kültürel yapının

* Prof. Dr., İstanbul Üniversitesi, İlahiyat Fakültesi, Dinler Tarihi Anabilim Dalı [sigunduz@gmail.com] 
ifadesidir. Cahiliyenin temelinde Allah'ın iradesi ve düzeni yerine dünyevi gücün/güçlerin insan yaşamında ana referans olarak kabul edilmesi bulunmaktadır. Bu durum, Allah'ın iradesinin insan düşüncesinde ve yaşamında belirleyici olmasını vurgulayan İslami öğretiye taban tabana karşıdır. Zira İslam'da Allah tek ilah, yani tek üstün karar verici güçtür ve tek egemendir. Sosyal, siyasal, ekonomik ve askeri gücün kutsanmasına bağlı olarak güçlünün her zaman haklı olduğuna dair bir algı cahiliyeye dayalı sosyal yapılarda egemendir. Bu algının her zaman toplumsal yapıda zulmün, baskının ve haksızlığın sebebi olduğu da bir gerçektir.

Anahtar Kelimeler: cahiliye, gelenek, statüko, kültürel yapı, güç, otorite, atalar kültü

\section{Giriş}

Kur'an'ın kullandığı bir kavram olarak cahiliyenin yalnızca belirli bir tarihsel dönemle ve bu döneme mensup bir kesimle ilgili olmadığı, tarihin her döneminde rastlanılan bir zihniyeti, bir hayat anlayışını ve kimliği ifade ettiği bilinen bir gerçektir. Esasen bu, Kur'an mesajının evrenselliği ve tarih boyu insan varlığına yönelik kapsayıcılığıyla da yakından ilişkilidir. Zira Kur'an, her ne kadar belirli bir tarihsel dönemde nazil olmuş olan bir kitap olsa da onun içerdiği mesaj yalnızca nazil olduğu dönemle ve kültürle sınırlı değildir. Kur'an mesajı kıyamete kadar her insana hitap eden ve insanları yönlendirmeye çalışan bir karakter taşır. Bu çerçevede, Kur'an'daki her bir ifade, söz konusu edilen her hadise ve karakterize edilen her şahsiyet, her ne kadar tarihsel bağlam itibarıyla belirli bir dönemle ilişkili olsa da taşıdığı anlam, mesaj, temsil ettiği karakter ve duruş itibarıyla tarih üstü bir mahiyet taşır; tarihin her döneminde yaşayan insana mesaj verir. Nitekim Kur'an'da söz konusu edilen hadiseler ve şahsiyetler, özü itibarıyla her zaman diliminde örneklerine rastlanılabilecek hususlardır. Bu nedenle Kur'an'da geçmiş dönem insanlık tarihinden kesitler sunan kıssalar önemli bir hacim oluşturur. Bu kıssalar vasıtasıyla insanlara çeşitli mesajlar verilir. Bu kıssalarda ilahi mesaja muhatap olan insanların/halkların takındığı olumlu ve olumsuz tutumlar evrensel karakterdedir. Kur'an'da anlatılan bu kissalarda, "halife" olarak yaratılan insana yönelik tevhid merkezli hak ve hakikat çağrısına dayalı ilahi davetle bu davete ya da çağrıya insanın verdiği cevaba yönelik tarihsel süreçte yaşanan olaylar hikâye edilir. Ardı ardına anlatılan bu kısaslarda ilahi çağrıyı insanlara ileten elçiler ve onların dilinden bu çağrının temel vurguları anlatılır. İlahi mesaja verilen 
cevaplar üzerinden olumlu ve olumsuz insan prototipleri verilir; hak ve batıl ya da tevhid ya da şirk mücadelesinin, Allah'a teslim olmuş muvahhid insan tipolojisiyle haddini aşan, kendine zulmeden müşrik insan tipolojisinin ana karakterler olarak tarih boyu mevcut olup birbirleriyle mücadele etmesi, örneklerle gözler önüne serilir. İlk insan Hz. Âdem'den Hz. Muhammed'e (s) kadar süregelen tarihi akış bizlere, peygamberlerin gönderildikleri topluluklarda temsil ve tebliğ ettikleri mesajları hatırlatır ve onlara karşı tutum ve tavırlardan örnekler verir. Bütün bunlarla Kur'an, bizlere, aslında tarihsel sürecin tevhid ve şirk mücadelesine sahne olan bir süreç olduğunu ve kıyamete kadar da bunun bu şekilde devam edeceğini anlatır. Bu gerçeği dikkate alarak, insanın içinde yaşadığı zaman diliminde kendisini ve çevresini doğru değerlendirmesi istenir.

Bu bağlamda Kur'an'da yer verilen kıssaların temel gayesi, insanlık tarihinden çeşitli örnekler vererek, tarih boyu başta peygamberler olmak üzere davetçilerin tebliğ ettikleri ilahi mesaja insanların nasıl cevap verdikleri konusunda hatırlatmalar yapılmasıdır. Bu hatırlatmalarda ise bir takım amaçlar hedeflenir. Yer verilen her bir kıssanın, Kur'an'da o kıssanın yer aldığı bölümde özel bir vurgusu olmakla birlikte, kıssalar Kur'an'ın geneline hâkim olan ana tema doğrultusunda insanları uyarmayı, ikaz etmeyi, ibret almalarını sağlamayı, onlara örnekler sunmayı, hatırlatmalarda bulunmayı, inananları teselli etmeyi, kalplerinin pekişmesini sağlamayı ve benzeri hususları amaçlar. ${ }^{1}$

Tıpkı geçmiş dönem toplumlarının yaşantısından kesitler sunan kıssalar gibi, Kur'an'ın nazil olduğu dönem toplum yapısıyla ilgili bilgiler sunan ayetler de karakterize ettiği şahsiyetler ve taşıdığı mesajlar itibarıyla evrensel bir anlam yüküne sahiptir; ilahi mesajla ilişkisi açısından insanın, toplumsal yapıların tutum ve tavırlarına yönelik oluşan prototipler ya da ilahi davete karşı insanın verdiği olumlu ve olumsuz yanıtlar konusunda bizlere örnekler sunar. Bu prototipleri ve ilahi davete karşı tutum ve tavırları yalnızca Kur'an öncesi dönemlerde ya da Kur'an'ın nazil olduğu dönemde değil tarihin her döneminde görmek

Bkn. Şinasi Gündüz, Kur'an'ı Anlamak; İlahi Vahyin Tarihe Açılımı, İstanbul: Mana 2015, s. 118-119. 
mümkündür. Böylelikle Kur'an'daki her bir kavram, şahsiyet ve olay insanlığa evrensel karakterler ve mesajlar sunmaktadır. Nitekim Kur'an'ın insanlığa yönelik inzal olunan ve kıyamete kadar korunan son kitap olmasının bir hikmeti de budur. ${ }^{2}$

\section{Kur'an'da Bir Kavram Olarak Cahiliye}

Kur'an'da yer alan cahiliye kavramı her ne kadar tarihsel bir bağlama sahip olsa da tarih üstü evrensel kapsamda bir zihniyeti ve duruşu karakterize etmektedir. Cahiliye teriminin geçtiği dört ayetin de Medine döneminde nazil olmuş olması dikkat çekicidir. $\mathrm{Bu}$ ayetler incelendiğinde Medine döneminde İslami değerler üzerine inşa edilen İslam toplumu ve bu toplumsal yapının üyesi olan Müslüman şahsiyetinin, farklı değerler üzerine bina edilen cahiliye toplumundan ve bu toplumdaki bireylerin karakteristik özelliklerinden mutlak ayrılığına dikkat çekildiği görülür. Müslümanlar, cahiliye geleneği ve bu geleneğin sahip olduğu zihniyet ve davranış biçimi konularında uyarılıp hak ve hakikat konusunda yönlendirilir. Örneğin Ali İmran 154'te Uhud savaşında yaşanan hadiselerle ilgili olarak bazı münafıkların Allah'a karşı cahiliye zihniyetine paralel bir zan ortaya koymaları kınanır ve onlarca Allah'ın her şeye hâkim olduğu, Allah'ın kudret, ilim ve iradesinin her şeyden üstün olduğu hususunun göz ardı ediliyor olması şiddetle eleştirilir. Mâide 49-50'de de hevâ ve heveslerinin peşinden giderek Allah'ın hükmüne riayet konusunda olumsuz tavır takınanlar, hâlâ cahiliye hükmünün izleyicileri olmakla kinanirlar.

“Aralarında, Allah'ın indirdiği ile hükmet. Onların arzularına uyma ve Allah'ın sana indirdiğinin bir kısmından (Kur'an'ın bazı hükümlerinden) seni şaşırtmalarından sakın. Eğer yüz çevirirlerse, bil ki şüphesiz Allah, bazı günahları sebebiyle onları bir musibete çarptırmak istiyor. İnsanlardan birçoğu muhakkak ki yoldan çıkmışlardır. Onlar hâlâ cahiliye hükmünü mü istiyorlar? Kesin olarak inanacak bir toplum için, kimin hükmü Allah'ınkinden daha güzeldir?"

2 “Şüphesiz o zikri (Kur'an'1) biz indirdik; onun koruyucusu da elbette biziz." Hicr, 9. 
Yine cahiliye teriminin yer aldığ $\breve{1}_{1}$ Fetih $26^{\prime}$ da ise cahiliye terimi hakikati inkâr edip ona sirt dönenlerin taassuplarıyla birlikte zikredilmektedir. Buna göre inkâr edenler kalplerine taassubu, cahiliye taassubunu yerleştirmişlerdir. Cahiliye teriminin geçtiği bir diğer yer olan Ahzâb sûresinde ise Hz. Peygamberin hanımları şahsında mümin hanımların taşımaları gereken hasletler zikredilir; onların cahiliye kadınlarından farklı oldukları, iffetlerini korumaları ve açılıp saçılmamaları gerektiği, ayrıca Allah'a ve Resulüne itaat ile namaz ve zekât konusunda hassas davranmaları hususu vurgulanir ${ }^{3}$.

Her ne kadar Kur'an'da bir terim olarak cahiliye yalnızca dört ayette geçse de özellikle Mekke döneminde nazil olan ayetlerin önemli bir kesimi cahiliye zihniyetini ve buna mensup olan insanları tanımlar. $\mathrm{Bu}$ ayetlerde bir yandan cahiliye geleneğinin inanç, düşünce, ahlak ve sosyal ilişkilere yönelik yapısı betimlenip eleştirilirken bir yandan da cahiliye geleneğine mensup insan tipolojisine çarpıcı örnekler verilir. Cahiliye geleneğinin insanları nasıl bir karanlığa, bağnazlığa ve aymazlığa mahkûm ettiği anlatılır.

Kur'an, Mekke döneminde somut ifadesini bulan hak ve hakikat dışı bu geleneği "cahiliye", buna mensup insanları da "cahiller" olarak isimlendirip, bu gelenek ve zihniyeti şiddetle eleştirirken bu gelenek bağlılarının kendi geleneklerini cahiliye olarak adlandırmamaları dikkati çekmektedir. Yani cahiliye isimlendirmesi, cahiliye dönemine ilişkin olarak Kur'an'ın yaptığı bir tanımlamadır. Kur'an, hak ve hakikatten uzak, insanları aymazlık içinde bırakan, akıllarını, fikirlerini kullanıp düşünmek yerine onları körü körüne kendilerine tevarüs etmiş olan geleneğe, kurulu toplumsal algılara ve kabullere dogmatik bir bağlılığa yönlendiren ve sonuç olarak da onları helake götüren bu geleneği "cahiliye", yani "aymazlık, hak ve hakikatten uzak olma" olarak nitelemiştir. Bu geleneğe bağlı insanlar da "cahiller"dir. Bu nedenle Müslümanlar, Mekke döneminde cahiliye zihniyetinin önde gelen figürlerinden Amr ibn Hişâm'1 "Ebû Cehil" olarak adlandırmışlardır. Cahiliye dönemi Araplarınca toplumdaki bilgeliği ve önderliği nedeniyle Ebu'l-Hakem yani “bilgeliğin babası" olarak adlandırılan bu şahsiyet, gerçekte Ebû Cehil, yani "aymazlığın babası"dır. Zira o, cahiliye zihniyetinin ve bu zihniyete bağlı geleneğin temsilinde öne çıkan bir kişiliktir. Hakikate

3 Ahzab, 32-33. 
gönlünü, gözünü ve kulağını kapatmış, körü körüne batılın peşinden giden ve insanları da buna yönlendiren, hatta zorlayan bir cahildir.

Kur'an, hakikate kulaklarını kapayan cahillerle Müslümanlar arasındaki kesin bir ayrışmanın altını çizer ve Müslümanları da bu konuda uyarır. Müslümanlar, cahiliye geleneğiyle ve zihniyetiyle aralarına mutlak bir set çekmeleri, cahiliye geleneğine mensup toplumdan ve kişilerden her yönüyle ayrışmaları ve hem bu zihniyetten hem de bu zihniyetin mensubu/bağlısı olan cahillerden uzak durmaları konularında uyarılır.

"Eğer onları, doğru yola çağırırsanız işitmezler. Sen onların sana baktıklarını görürsün, hâlbuki onlar görmezler. Sen af yolunu tut, iyiliği emret, cahillerden yüz çevir." 4

Yine Kur'an'da müminler bu geleneğin bağlısı olan cahillere aldırış etmemeleri, örneğin onların kendilerine sataşmaları söz konusu olduğunda "selam" deyip geçip gitmeleri konusunda yönlendirilir.

“Rahmân'ın kulları, yeryüzünde vakar ve tevazu ile yürüyen kimselerdir. Cahiller onlara laf attıkları zaman, "selâm!" der (geçer)ler." 5

Kur'an, nüzulü dönemi cahiliye geleneğinden verdiği bu örneklerle bizlere cahiliyenin ana çerçevesini verir ve cahiliye düşüncesine ve bu düşünceye sahip olan insanın tabiatına yönelik bilgi sunar. Verdiği bu bilgiler ve yaptığı tanımlamalarla bugün ve gelecekte başta kendi inanç, düşünce, tavır ve davranışlarımız olmak üzere içinde yaşadığımız toplumu ve çevremizi değerlendirmemizi, bir muhasebe yapmamızı ister. Zira geçmişte olduğu gibi bugün ve gelecekte de cahiliye geleneği ve bu geleneğe mensup insanlarla toplumlar varlıklarını sürdürmektedirler; cahiliye geleneğinin dayanağını oluşturan değer yargıları ve bu değer yargılarına dayalı yaşam biçimi toplumsal yapıya egemendir. İnsanlar bu toplumsal yapıyı cahiliye olarak adlandırmasalar, hatta içinde bulundukları fiili durumu ehli haktan saysalar da Kur'an'ın cahiliye geleneğine ve bu geleneğe bağlı insanlara yönelik tasvir ve

$4 \quad$ A'raf 198-199.

5 Furkan 63. 
tanımlamaları dikkate alındığında cahiliye zihniyetinin hâlâ insanlık üzerinde tahakkümünü sürdürdüğü görülür.

\section{Bir Kültürel Yapı Olarak Cahiliye}

Bir gelenek olarak cahiliye bir kültürel yapının, bir zihniyetin, bir yaşam ve düşünce/inanış biçiminin ifadesidir. Sahip olduğu gelenek ve görenekleri, adetleri, sosyal kurumları, hak ve hakikat anlayışı, insan ve dünya görüşü ve metafizik inançları ile cahiliye kültürel bir yapı arz eder. Bu kültürel yapı, ölçü olarak aldığı referansları, dayanakları, yaşamın anlamına ve amacına yönelik bakış açısı ve hakikat ve kurtuluş düşüncesi açısından kendi değer yarg1larına sahiptir. Bu değer yargılarıyla cahiliye geleneği kendi mensuplarına bir kimlik sunar; bu kimlik cahiliye kimliğidir. Kültürel bir yapı olarak cahiliye ve bir kimlik olarak cahiliye kimliği İslam'ın ve Müslüman kimliğinin karşıtını oluşturur. İslam ile cahiliye ve İslami kimlik ile cahiliye kimliği birbirine taban tabana zıttır, yapıları itibarıyla birbirinden tamamen farklıdır ve birbirine karşıttır. Bu iki farklı kimlik temel dayanakları, referansları, insanın yeryüzündeki var oluşuna ve varoluş gayesine bakışları açısından birbirinden tamamıyla farklı bir duruş sergiler. Cahiliye geleneği temel referansını yerleşik gelenekten ve bu geleneğe yön veren insan hevâ ve hevesiyle dünyevi güçlerden alırken İslami kimlik temel referansını Allah'ın kitabından alır. İlk insan Âdem'den itibaren Müslüman kimliği bu referans doğrultusunda ilahi mesaj temelinde kendisini inşa eder. Esasen insanı "yeryüzünde bir halife" yapan ve "en güzel surette yaratılan bir varlık" olarak meleklerin bile "secde etmeleri" istenilen bir varlık olması insana özgü bu Müslüman kimliğiyle yakından ilgilidir. Aksi takdirde, yani Müslüman kimlik yerine hevâ ve hevesinin esiri olan ve cahiliye kimliğine bürünen insan "aşağ1ların aşağısında” bir vasfa bürünür. Burada İslam'ın ve Müslüman kimliğin, Hz. Muhammed'le ya da ona vahyolunan Kur'an'la birlikte başlamadığını, İslam'ın ilk insanla birlikte hayatın doğru okunması, algılanması ve bu çerçevede bir yaşam, düşünce ve inancın bina edilmesi için Allah tarafından vaz olunan hak dinin adı olduğunu vurgulamakta yarar vardır. Tarih boyu bu dine, İslam'a inanan bütün müminler Müslüman olarak isimlendirilmiştir ve bütün peygamberler Allah'ın kitabını, mesajını insanlara ileten ve bu mesajın anlaşılıp yaşanması konusunda insanlara örnek, rehber ve öğretmen olan birer İslam peygamberidirler. İslami kimliğin 
belirleyici, ayırt edici özellikleri İslam'ın temel değerleridir. Bu değerlerden en başta geleni, insanın hayattaki en temel ve belirleyici referansı olarak Allah'ın iradesinin beyanı olan kitabı, yani ilahi mesajı kendisine düstur edinmesidir. Esasen bu, bütün varoluşta Allah merkezliliği ifade eden tevhid ile de yakından ilgilidir. İslam'ın temel bir öğretisi olarak tevhid, yalnızca metafizik ve varlık bağlaminda değil her anlamda varoluşa ve hayata Allah merkezli olarak bakmak, inancı, düşünceyi, tutum ve davranışları kısacası yaşamı Allah merkezli olarak tesis etmek demektir. Bu doğrultuda Müslüman, yaşamında öncelikle Allah'ı, Allah'ın iradesinin beyanı olan kitabı, yani Kur'an'ı temel referans edinen ve buna göre tutum ve davranışlarını belirleyen kişidir. Hayata tevhid ilkesi doğrultusunda bakan insan, yaşantısında tek üstün güç yani ilah olarak Allah'1 kabul eder ve ona hiçbir konuda hiçbir şeyi denk tutmaz. Ayrıca tüm tavır ve davranışlarında yalnızca Allah'ın iradesine riayet etmeyi, onun koymuş olduğu sınırları gözetmeyi, Allah'a itaat vesilesiyle ona yakınlaşmaya çalışmayı, yani takvayı gaye edinir. Müslüman insanın yaşamının temel kaynağı, referansı ve motive edici gücü Allah'ın iradesidir; Allah'ın mutlak otoritesi ve hâkimiyeti dişında hiçbir güç odağı onun yaşamında yönlendirici, belirleyici olamaz.

İslami kimliğin belirleyici bu temel değeri karşısında cahiliye kimliği dünyevi güç odaklarını ve insan merkezliliği kendi değer yargılarında belirleyici faktörler olarak ön plana çıkarır. Cahiliye kimliğinde, otorite ve hükümranlık bağlamında insanların hevâ ve hevesleri ile arzuları ve hırsları belirleyicidir. Kur'an, cahiliye dönemi Arap geleneği mensuplarından bahsederken "hevâ ve hevesini ilah edineni görmez misin?" 6 diye o dönem cahiliye insanlarının yaşamında belirleyici bir faktör olarak ön plana çıkan ve menfaatin kişileri yönlendiren bir güç olmasına dikkat çekmektedir. Bunun dişında sahip olunan mal mülk, servet ve evlat ya da adam kişilerin sosyal yapıda güçlülüklerinin ya da haklılıklarının bir delili olarak kabul edilmektedir. İnsanların haklı görülüp görülmemeleri ya da doğru ve yanlış anlayışları esas olarak bu hususlardan hareketle değerlendirilmektedir.

6 Furkân 43; Câsiye 23. 
Tevhid ilkesi doğrultusunda İslam'ın esas edindiği temel değerlerden bir diğeri ise adalettir. Adalet, insanın gerek sosyal gerekse doğal çevresine yönelik tutum ve davranışlarında gözetmesi gereken temel bir ilkedir. Tarih boyu peygamberler adil olmanın ve adil davranmanın önemini vurgulamışlardır. Adaletin şaşmaz bir terazi olarak mümin insanın yaşamında egemen olması istenmiştir. Öyle ki Kur'an'da kendisi ya da en yakınları aleyhine bile olsa insanların adaletten taviz vermemeleri gerektiği vurgulanmakta, bir topluluğa olan kin ve düşmanlığın kişiyi adaletsizliğe sevk etmemesi istenmektedir.7 Adalet, iyilik ve doğruluk ilkeleri doğrultusunda İslam, iyiyi emretmek ve kötülükten sakındırmak şeklinde özetlenebilecek el-emri bi'l-maruf ve'n-nehyi ani'l-munker ilkesini toplumu oluşturan bireyler arasında hak, hakikat ve adalet yönünde birbirlerine yönelik bir oto kontrol mekanizması olarak canlı tutar. Farz-1 kifâye olarak kabul edilen bu ilke doğrultusunda insanlar sosyal yapıda cereyan eden, şahit oldukları her durumda hakkın, hakikatin ve adaletin yanında taraf olma durumundadırlar. Buna karşılık cahiliye geleneğinde adalet yerine güçlünün hukukunun gözetilmesi, insanlara sosyal, askeri ve ekonomik güç ve değerlerine göre muamele edilmesi ilkesi esas alınmaktadır. Toplumda sosyal yapı bu güç dengeleri çerçevesinde adı konulmuş ya da konulmamış kast tabakalarından oluşur. İnsanlara sahip oldukları ekonomik, politik, sosyal ve askeri güçlerine göre muamele edilir. Bu doğrultuda cahiliye kültürü zulüm üreten ve zulmü meşrulaştıran bir sosyal yapı arz eder.

İslami kimliğin üzerine bina edildiği vaz geçilmez değerlerden bir diğeri ise güzel ahlaktır. İslam, ahlaki ilkeler bağlamında kişinin Allah'a, kendisine ve içinde yaşadığ ğunu vurgular. Allah'a karşı sorumluluk kişinin tutum ve davranışlarında Allah'ın koymuş olduğu sınırları gözetmesi, ahlaki zafiyetlerden her şeyden önce Allah'ın koymuş olduğu düzene aykırı oldukları için uzak durmasıdır. Kendisine karşı sorumluluğu ise güzel ahlaki tutum ve davranışlarla, Allah'a itaatkâr/bağlı bir kul olma vasfina riayet etmesi, Kur'an'ın ifadesiyle kendisine zulmetmemesidir. İçinde yaşadığı topluma karşı sorumluluk ise insanın tutum ve davranışlarıyla çevresine yönelik bir rol model olmasıyla yakın irtibatlıdır. Zira insan olumlu ve olumsuz her davranışıyla, bu

$7 \quad$ Bkn. Mâide 8; Nisâ 135. 
davranışlar fiili sonuç itibarıyla yalnızca kendisine dönük bir durum üretiyor olsa bile, çevresine bir örneklik teşkil etmektedir. Bu durumda sergileyeceği güzel ahlak ya da bunun tersi tutumlar çevresini dolaylı olarak etkileyecektir. Bu sorumluluk doğrultusunda kişi olumlu ahlaki tutum ve davranışlarla yükümlü tutulur. Cahiliye geleneğinde ise kişinin tutum ve davranışlarında belirleyici olan, toplumsal yapıda kurulu gelenek ile çıkar ve menfaatler ve kişisel hazlardır.

Gerek Arap cahiliye geleneğinde gerekse günümüz cahiliye geleneklerinde tutum ve davranışlarda Allah'ın belirlemiş olduğu sınirlar değil, toplumda cari olan adet ve uygulamalar esas alınmaktadır. Ahlaki yönden neyin doğru ya da neyin yanlış olduğu, neyin iyi ya da kötü olduğu, toplumların oluşturdukları sosyal düzen ve gelenekler tarafından belirlenip düzenlenmektedir. Bu doğrultuda örneğin, içinde yaşanılan toplumsal yapıda "hukuka uygun olma" ya da belirli durumlarda "başkalarına zarar vermeme" ilkesi tutum ve davranışlarda mutlak belirleyici olarak kabul edilmektedir. Yaşanılan toplumda yapılan bir davranış hukuka bir şekilde uygunsa ya da uydurulmuşsa bunun meşru ve doğru kabul edildiği varsayılmaktadır. Örneğin cahiliye dönemi Arap toplumunda işlerine geldiği gibi haram ayların yerlerinin değiştirilmesi geleneğinin altında böylesi bir ahlaki zafiyet yatmaktadır. Gücün ve güçlünün üstünlüğünün ve haklılığının adı konulmamış bir hukuki ilke olarak kabul gördüğ̈̈ bu toplumda, rakip kabileler zayıf duruma düştüklerinde savaş ve çatışmanın haram olarak kabul edildiği haram ayların yerlerini değiştirerek rakiplere saldırmak ve mal ve mülklerini müsadere etmek ahlaki bir sorun olarak görülmüyordu. Zira yapılan yürürlükteki merci geleneğe uygundu. Benzer şekilde günümüz cahiliye geleneklerinde de amiyane bir ifadeyle "işi kitabına uydurarak" yapılan her tutum ve davranış meşru görülmekte, bunda bir ahlaki zafiyet görülmemektedir. Tutum ve davranışlarda başkalarına zarar vermeme prensibinin esas alınması da aynı şekilde gerek cahiliye dönemi Arap toplumunda gerekse günümüz cahiliye geleneklerinde yaygındır. Herhangi bir eylem örneğin zina, kumar ya da intihar gibi eylemler, şayet sonuçları itibarıyla yalnızca bu eylemde bulunan kişilerle sınırlı kalıyor ve başkalarına zarar vermiyorsa bunlar gayri ahlaki görülmemektedir. Bu doğrul- 
tuda cahiliye dönemi Arap toplumunda zinanın oldukça yaygın olduğu, hatta Hz. Ayşe'den nakledilen bir hadiste görüleceği üzere, ${ }^{8}$ zinanın nikâh formatında bir meşruiyet zeminine oturtulduğu bilinmektedir. Günümüzde de birçok toplumda söz konusu kişiler arasında bir anlaşma mevcutsa, İslam'ın zina olarak tanımladığı davranışların meşru olduğuna dair hukuki düzenlemeler olduğu ve toplumda bunun kabul edilerek içselleştirildiği bilinen bir gerçektir. Yine başta neo-pagan akımlar olarak adlandırılan gelenekler olmak üzere çeşitli sosyal yapılarda, topluluklarda "başkalarına zarar vermiyorsa her şey yasaldır/doğrudur" ilkesinin esas alındığı bilinmektedir. ${ }^{9}$

Metafizik değerlere yer verip vermemesi açısından cahiliye kültürü çok yönlü, çoğulcu bir yapıya sahiptir. Gerek tanrı inancı gerekse yeniden diriliş ve ölüm sonrası yaşam konusunda cahiliye mensupları arasında farklı yaklaşımlar görülebilir. Örneğin, cahiliye dönemi Arapları arasında zamanın mutlak belirleyiciliğini ve insan yaşamının içinde bulunulan zamanla sınırlı olduğunu düşünen bir çeşit materyalistler olduğu gibi ${ }^{10}$, Allah'ın yaratıcılığını ve yok ediciliğini kabul eden, melekler ve cinler gibi çeşitli metafizik varlıklara inançlarında yer verenler de vardır. Bununla birlikte Kur'an'ın nazil olduğu dönem Araplarının genelde politeist/çok tanrıcı ve pagan/putperest oldukları bilinmektedir. Onlar, çok tanrıcılık ve paganizmi mutlak üstün olan bir Allah inancıyla birleştirmişlerdir. Allah, cahiliye Araplarının tanrılar panteonunun zirvesinde yer alan üstün ve aşkın varlıktır. $\mathrm{O}$, bir bakıma tanrılar tanrısı ve ilahlar ilahıdır. Üstün ve mutlak aşkın bir varlık olarak Allah'ın yaratıcılığını, yöneticiliğini, rızık vericiliğini kabul ederler. ${ }^{11}$ Ancak onun tek tanrı ya da tek ilah olduğunu kabul etmezler.

8 Buhari, Sahih, Nikah 36.

9 Bkn. Şinasi Gündüz, Anadolu'da Paganizm: Antik Dönemde Harran ve Urfa, Ankara: Ankara Okulu 2005.

10 “Dediler ki: “Dünya hayatımızdan başka hayat yoktur. Ölürüz ve yaşarız. Bizi ancak zaman yok eder." Bu hususta onların bir bilgisi yoktur. Onlar sadece zanda bulunuyorlar." Câsiye 24.

11 "Andolsun, onlara, "Gökleri ve yeri kim yarattı, güneşi ve ayı hizmetinize kim verdi?" diye soracak olsan mutlaka "Allah" diyeceklerdir. O hâlde nasıl döndürülüyorlar? Allah, kullarından dilediğine rızkı açar da kısar da. Şüphesiz Allah, her şeyi bilendir. Onlara, "Gökten yağmuru kim indirip de onunla yeryüzünü 
Zira Allah, insanların kendisine doğrudan ulaşamayacakları kadar üstün ve aşkın olan bir ulûhiyettir; bu nedenle ona ulaşmak için bir takım aracılara, diğer ilahlara ihtiyaç vardır. ${ }^{12} \mathrm{Bu}$ aracılar vasıtasıyla onunla irtibat kurmak ve ona ulaşmak mümkündür. Yine bu arac1ların şefaatiyle, tavassutuyla Allah indinde arınıp kurtulacaklarını düşünmektedirler. Üstün güç olduğuna, yani ulûhiyetine inanılan bu aracılar arasında Lât, Menât, Uzza gibi birtakım putlar olduğu gibi kabile, soy-sop, geçmiş atalar, sahip olunan evlat, servet, mal mülk gibi değerler de bulunmaktadır. Bu aracı metafizik ve dünyevi varlıklar ve değerler, kişinin yaşantısında yöneldiği, yardımına başvurduğu, kendisine referans aldığı unsurlardır; bunlar kişilerin tavır ve davranışlarına yön veren mercilerdir. Cahiliye Arapları, Allah'la birlikte bunlara da yönelmeyi, yaşamlarında bunların iradelerini de esas almayı bunlara da ibadet etmenin gerekliliğine inanmakta ve Hz. Peygamber ve müminlerle bu konuda tartışmaktadırlar.

“De ki: “Ey cahiller! Siz bana Allah'tan başkasına ibadet etmemi mi emrediyorsunuz?" 13

Gerçekte cahiliye mensuplarının inançlarında yer verdikleri Allah, mutlak aşkınlığından dolayı bir bakıma dünyadan el etek çekmiş, adeta emekliye ayrılmış bir yüce varlıktır. Kur'an bunu Allah'ı gereği gibi takdir edememek olarak tanımlamaktadır.

"Allah'ı gereği gibi takdir edemediler. Yeryüzü kıyamet gününde bütünüyle O'nun elindedir; gökler sağ eliyle dürülmüştür. $\mathrm{O}$, onların ortak koştuklarından münezzehtir, yücedir."14

Araplar, bu yüce varlığın yalnızca ontolojik ve metafizik anlamda yüceliğini, yaratıcılığını ve düzen vericiliğini kabul etmekte; ancak onun yarattığ bu evrene ve insana yönelik mutlak egemenliğini, yöneticiliğini, başvurulacak tek hüccet oluşunu ve yegâne hüküm koyuculuğunu kabul etmemekteydiler. Zira dünyevi alanda, toplumsal yapıda mutlak egemen olan, yönetici, yönlendirici ve hü-

ölümünden sonra diriltti?" diye soracak olsan, mutlaka, "Allah" diyeceklerdir.

De ki: "Hamd Allah'adır." Fakat onların çoğu akletmezler." Ankebût 61-63.

Zümer 64.

14 Zümer 67. 
küm verici konumunda bulunan başka güçler vard1; zenginler, güçlüler, gelenek, görenek, kabile taassubu, sermaye, silah vb. gibi... Bu hastalıklı ulûhiyet tasavvurları yanında cahiliye Arapları, özellikle de ileri gelen eşraftan olan kimseler yeniden diriliş, hesap, yarg1 ve ölüm sonrası yaşam konularında da derin bir şüphe içindeydiler. İslam tarihi kaynaklarından edinilen bilgiler çerçevesinde halkın genelinde bir öte dünya inancı var olmakla birlikte, toplumun ekâbir takımı genelde yeniden diriliş ve hesabı sorgulamakta ve bu konuda müminlerle tartışmaktaydılar.

"Ve bizim hayatımız, dünya (hayatından) başka bir şey değildir. Ve: "Biz tekrar diriltilecek değiliz." dediler." 15 "Kendi yaratılışını unutarak bize bir örnek verdi; dedi ki: "Çürümüş bozulmuşken, bu kemikleri kim diriltecekmiş?" 16

“Ve “Biz, kemik ve kırıntı olduğumuz zaman mı? Gerçekten biz, mutlaka yeni bir yaratılışla mı diriltileceğiz?" dediler." 17

Yeniden dirilişi ve hesabı tartışma konusu edinen bu kişiler, sahip oldukları mal mülk, servet ve adam/evlat gücüyle, zaten bu dünyada seçilmiş, korunmuş ve gözetilmiş olduklarını düşünmekte, dolayısıyla kendilerine yönelik ilahi rahmetin bu dünyada gerçekleştiğini var saymakta ve bu durumda ölüm sonrası bir öte dünyanın gerekliliğine inanmamaktaydılar. Metafizik değerlere yönelik bu inanç sistemleriyle cahiliye insanları kendilerinin hakikat ehli ve kurtulanlardan olduklarını; Hz. İbrahim'in geleneğini sahiplendiklerini iddia ederler. Bir başka ifadeyle onlar Hz. İbrahim'in tesis ettiği dinin varisleri olduklarına inanırlar. ${ }^{18}$

\section{Güce Dayalı Bir Haklılık Algısı ve İktidar Yapılanması}

Cahiliye kültürü bir bütün olarak bakıldığında sahip olunan gücün kutsandığı ve güce dayalı bir haklılık algısının egemen olduğu bir zihniyetin ifadesidir. Statüko güçlünün haklı olduğu bir algıya toplumsal yapıda bir meşruiyet kazandırmıştır. Burada söz konusu

15 En'am 29. Ayrica Nahl 38; Nâziat 10-12.

16 Yâsîn 78.

17 İsra 49.

18 Buna karşılık Kur'an'ı Kerim Hz. İbrahim'in hanif bir Müslüman olduğunu ve müşriklerden olmadığını defaatle vurgular. Örneğin bkn. Ali İmrân 67; Nahl 120; En'am 79; Bakara 135. 
olan güç ise esas itibarıyla insan ve insanın sahip olduğu siyasal, ekonomik ve askeri değerler merkezli bir güçtür. Bu yapıda sahip olunan güç ile esasta metafizik bağlamda bir irtibat bir ilişki de kurulmaktadır. Şöyle ki, cahiliye insanına göre kişilerin sahip oldukları güç, esas itibarıyla onların ilahi seçilmişliklerinin dolayısıyla haklılıkların da bir göstergesidir. Zira onlar sıradan insanlar olsalar, onlara sahip oldukları bu güç verilmezdi. Bir başka ifadeyle güce dayalı dünyevi iktidarlar tanrısal âlem tarafından onaylanan, desteklenen hatta belirlenip tesis edilen bir yapıdadır. Bu nedenle örneğin Allah'ın kendisine ihsan ettiği mallar ve oğullarla, yani güçle adeta kendisinden geçen, bunlarla böbürlenip şımaran ve haddini aşan Velid ibn Muğire gibi kişiler, içinde yaşadıkları toplum tarafından hak ve hakikat konusunda karar verecek bir merci olarak düşünülmüşlerdir. Nitekim Kur'an'da ona Kur'an mesajının ne'liği konusunda hüküm vermesi, karar vermesi için başvuran kişilere o, bunun ancak bir insan sözü olduğunu söylemiştir. ${ }^{19}$ Esasen sahip olunan güç, iktidar ve ilahi haklılık ya da bunun metafizik meşruiyeti hususu yalnızca Kur'an'ın nazil olduğu dönem cahiliye Arap toplumunda değil cahiliye kültürüne mensup bütün toplumlarda görülür. Örneğin Hıristiyan geleneğinin mimarı olan Pavlus, bir deyişinde bunu temel belirleyici bir kural olarak ifade etmekte ve iktidar/güç ve ilahi haklılık dolayısıyla da güce/iktidara mutlak teslimiyet vurgusu yapmaktadır. Pavlus Romalılara Mektubunda, "herkes altında bulunduğu yönetime boyun eğsin. Çünkü Tanrıdan olmayan yönetim yoktur; var olanlar Tanrı tarafından kurulmuştur. $\mathrm{Bu}$ nedenle yönetime karşı direnen, tanrının düzenlediğine karşı gelmiş olur ..." 20 demektedir. Benzer şekilde günümüz yönetim sistemlerinde de esas olarak genelde insanların özelde ise gücü iktidarı elinde bulunduranların haklılığ 1 ve egemenliği üzerine adeta bir uzlaşma olduğu dikkati çekmektedir. İktidar ve hâkimiyet hakkının mutlak anlamda halkta ve halkın iradesinde gerçekleştiği anlayışı genel kabul görmektedir. Bununla birlikte gerçekte iktidar ve hâkimiyet halkla birlikte, halk adına ya da halka rağmen gücü elinde tutanlar tarafından sahiplenilmektedir. İslam, ister genel anlamda

19 “Çünkü o, düşündü taşındı, ölçtü biçti. Kahrolası nasıl da ölçtü biçti! Yine kahrolası, nasıl ölçtü biçti! Sonra baktı. Sonra surat astı, kaşlarını çattı. Sonra arkasını döndü ve büyüklük taslayıp şöyle dedi: "Bu, ancak nakledilegelen bir sihirdir. $\mathrm{Bu}$, ancak insan sözüdür." Müddessir 18-25.

20 Romalılara Mektup 13:1-7. Bkn. Şinasi Gündüz, Pavlus: Hıristiyanlı̆̆ın Mimarı, Ankara: Ankara Okulu 2001, s. 224-226. 
insanlar ya da halk, isterse belirli kişi ve gruplar olsun kaynağını dünyevi güçten/güçlerden alan bir iktidar ve egemenlik anlayışına karşı çıkmakta; iktidar ve egemenliğin mutlak anlamda Allah'ta olduğunu, tek hüküm merciinin Allah olduğunu ve insanın ancak Allah'ın koymuş olduğu sınırlar çerçevesinde yeryüzünde yaşamını sürdürebileceğini, bunun aksinin ise haddi aşma ve kendine zulmetme olacağını belirtmektedir. Zira İslam'da gücün yegâne merkezi ya da mercii Allah'tır; dolayısıyla her durum kendisini bu gücün iradesinin beyanı olan kitaba, yani Allah'ın kitabına dayandırdığı oranda meşrudur. Cahiliye geleneğinde ise gücün merkezi Allah değil insanlardır; belirleyici olan Allah'ın iradesi değil insanın/insanların iradeleridir. Güç merkezleri, esas olarak yeryüzünde gücü fiili olarak elinde bulunduran kişiler ve kurumlardır. Bunların elinde bulundurdukları, sahip oldukları güç ile hak ve hakikat iddiaları arasında yakın bir ilişki olduğu kabul edilir. Hatta bu bağlamda Kur'an'ın nüzulü döneminde cahiliye Arapları risâlet ve Allah katında seçkin olmak gibi hususların bile kişilerin sahip oldukları güce göre değerlendirilmesi gerektiğini düşünmekteydiler. Onlar bundan hareketle Hz. Muhammed'in risâletine karşı çıkmakta ve risâletin olsa olsa gücü elinde bulunduran iki zengin kişiden birisinin hakkı olabileceğini ileri sürmekteydiler. Zira Hz. Muhammed'in sosyal statüsü ve ekonomik durumu böylesi bir seçkinlik için onlara göre uygun değildi.

“Bu Kur'an, iki şehrin birinden bir büyük adama indirilmeli değil miydi?' dediler. Rabbinin rahmetini onlar mı bölüştürüyorlar? ..." 21

Mekkeli müşriklerin burada Peygamberliği yakıştırdıkları kişiler Mekkeli Velid ibn Muğîre ile Tâifli Urve ibn Mes' ûd es-Sekafî idi. Onlar, Hicaz bölgesinin bu iki önemli kentinin en varlıklıları ve güçlüleri olarak bilinen bu iki şahıs dururken, Hz. Muhammed'in (s) peygamber olmasını içlerine sindiremiyorlardı. Çünkü bu durum, yaşadıkları toplumda belirleyici olan güç algısına aykırıydı. Oysa yukarıdaki ayeti kerimeye de yansıdığı şekilde, risâlet görevi Allah'ın bir rahmetidir ve Allah'ın rahmetini paylaştırmak ya da bu rahmetin kime yönelik olup olmaması insanın görevi değildir; Allah rahmetiyle dilediğini nimetlendirir.

21 Zuhrûf 31-32. 
“Ne Ehli Kitaptan inkâr edenler ne de müşrikler Rabbinizden size bir hayır indirilmesini isterler. Allah rahmetini dilediğine tahsis eder; Allah büyük lütuf sahibidir." 22

Dünyevi güç ve iktidar sahibi olmanın mutlak haklılığın referansı olarak görülmesi konusunda günümüz cahiliye toplumsal yapılarında da durum değişik değildir. Örneğin birçok çağdaş toplumsal yapıyı adeta esir alan kapitalizmin mutlak iktidarı sermayedir, maldır ve paradır. Sermaye, mal ve para önünde insanlar tüketen ve tükettikleri oranda sermaye sahiplerine servet kazandıran birer figürandır; para ve sermaye önünde onlar yalnızca birer istatistik malzemesidir. Yine birçok günümüz toplum yapılanmasında yalnızca totaliter idareciler ve despot yönetimlerde değil, halkın iradesinin ön plana çıkarılmaya çalışıldığı yapılarda da belirli zümrelerin, iktidar mensuplarının, güçlülerin ya da halkın genelinin çıkar ve menfaatlerinin esas alındığ kötü, meşru olan ve olmayan ya da doğru ve yanlış gibi değerlendirmelerde Allah'ın koyduğu sınırlarla belirlediği esaslar değil, insanların çıkar ve menfaatlerine, arzu ve yönelimlerine göre bir değerlendirme yapılmakta; her türlü değer yargısı bu ilkeler/esaslar doğrultusunda yapılmaktadır.

\section{Atalar Kültü ve Geleneğin Kutsanması}

Kur'an, inzal olan ilk ayetinden itibaren insanları etrafında olup bitenler konusunda düşünmeye ve sorgulamaya davet etmiştir. Nitekim ilk inen ayetler insandan okumasını, Rabbinin adıyla okumasını istemektedir. ${ }^{23}$ Yine Kur'an, cahiliye mensuplarını, aklını ve duyularını kullanmamakla, kör, sağır ve dilsiz olmakla itham eder. ${ }^{24}$ Cahiliye mensuplarına yönelik bu suçlamaların en temel nedeni onların içinde yaşadıkları toplumda kendilerine dayatılan alg1ları sorgulamamaları, statükoyu körü körüne sahiplenmeleri ve kendilerine tevarüs eden geleneğe körü körüne bağlanmalarıdır.

Cahiliye geleneğinin en çarpıcı karakteristik özelliklerinden birisi geleneğin kutsanmasına dair statükonun sıkı sıkıya sahiplenilmesidir. Öteden beri sürdürülegelen gelenek ve görenekler, adetler, inanışlar ve toplumsal yapılar insanların yaşamında belirleyici bir

22 Bakara 105. Ayrıca bkn. Gündüz, Kur'an'ı Anlamak, s. 97.

23 Alak 1-5.

24 Bkn. Bakara 18, 171; En’am 139; Neml 80; Rum 52; Zuhruf 40. 
role sahiptir. Bu doğrultuda örneğin Kur'an'ın nazil olduğu dönem cahiliye Arapları için kabile değerleri ve kabile bağları bir kişinin hayata bakışında son derecede önemlidir; kabile taassubu sosyal ilişkilerde ve algılarda oldukça belirleyicidir. Bir kişinin hangi kabileye ve kabile içinde hangi aileye mensup olduğu toplumdaki hiyerarşik konumu ve kendisine yönelik tutumlar açısından önemlidir. Yine o dönemde nesilden nesle sürdürülen inanç ve düşüncelerle adetler kutsaldır. Bu nedenle onlar Kur'an'ın tek Allah'ın ulûhiyetini ve ona hiçbir şeyi ortak tutmamayı vurgulayan tevhid akidesine kaşı çıktılar. Zira onlara göre Kur'an'ın bu çağrısı, atalarından miras aldıkları düşüncelere ve inanışlara aykırıydı. Bu yeni söylem nevzuhur bir şeydi ve dolayısıyla kabul edilemezdi; bu nedenle de İslam'a karşı şiddetle muhalefet ettiler.

Atalar kültü olarak adlandırılan geçmişten miras alınan geleneğin kutsanması yalnızca cahiliye dönemi Araplarında değil tarih boyu birçok topluluğun temel karakteristik özelliği olarak karşımıza çıkmaktadır. Eski Roma ve Yunan'dan Eski Mısır ve Mezopotamya kültürlerine kadar birçok kültürel yapıda atalardan tevarüs eden gelenek kutsanmakta ve mevcut sosyal, kültürel düzenler ve iktidarlar meşruiyetlerini bu geleneğe dayandırmaktadırlar. Örneğin birçok toplumda krallar, imparatorlar, kabile reisleri, zenginler ve diğer ileri gelenler güç ve iktidarlarını geleneğe dayandırmışlardır. Zira bağlı olunan gelenek iktidarların ilahi bir ihsan ve onayla tesis edildiğini ve iktidarlar tarafından yürütülen siyasetin ve icraatın ilahi bir meşruiyet zeminine sahip olduğunu kabul etmiştir. Bu doğrultuda örneğin kral Hammurabi'nin hazırladığ1 meşhur hukuk metinlerinin kendisine tanrı Şamaş tarafından verildiğine inanılmıştır. ${ }^{25}$ Bununla Hammurabi, bu yasaları halka dayatırken bu metinleri kendi kafasından yazıp hazırlamadığını, ilahi âlemde tanrı Şamaş'ın bunları kendisine verdiğini ve kendisinin de tanrının bu emirlerini yerine getirdiğini söylemek suretiyle kendi otoritesini ve iktidarını meşrulaştırmıştır. Benzer şekilde Roma'da Sezarların ya da Mısır'da firavunların iktidarlarındaki en önemli dayanakları toplumda cari olan gelenek olmuştur. Zira bu gelenek, onların iktidarının ilahi bir meşruiyete sahip olduğunu vurgulamakta ve kral ve yöneticilerin tanrının soyundan geldiğini ya da tanrısal kelâmın yeryüzünde hulul etmiş hali olduğunu söylemekteydi.

25 Bkn. Joseph Wheless, Is it God's Word, New York: Kessinger, 2007, s. 69. 
Bu çerçevede cahiliye Arapları arasında da gelenek, sorgulanmaksızın bağlanılması gereken bir değer olarak kabul görmüştür. Onlara göre bu gelenek referansını babalarının, dedelerinin yol ve yönteminden almaktadır. Cahiliye Arapları metafizik ya da dünyevi her değer ve hususu bağlanmış oldukları bu gelenek doğrultusunda ele almaktaydılar. Örneğin yukarıda da değindiğimiz gibi, Allah'a inanıyorlardı, fakat inandıkları Allah, tek üstün güç ya da ilah olan bir Allah değildi; zira o evreni yaratan, rızıklandıran, her şeyin sahibi olan bir varlıktı, ama mutlak aşkındı, doğrudan ulaşılamayacak kadar yüceydi. Dolayısıyla onun evrene ve insana yönelik doğrudan bir tasarrufu söz konusu değildi. Bu bağlamda metafizik düzlemde dua ve yakarışları ona iletecek aracılara, dünyevi bağlamda ise tanrı adına yeryüzünde iktidarı yürütecek birilerine, yani kabile reislerine, eşraftan olanlara ve güçlülere ihtiyaç vard1. Böylelikle otorite, egemenlik, yönetme, sahiplik başta olmak üzere birçok konuda Allah'a birçok şeyi, kişiyi ve kurumu ortak koşmada yani şirkte bir beis görmediler.

Atalar kültü ve geleneğin kutsanmasında cahiliye insanlarının temel referansı yine geleneğin kendisidir. Mevcut geleneğe ilahi irade adına bir meşruiyet kazandırılmıştır, bunun Allah'ın düzenine aykırı olmadığı tam tersine uygun olduğu iddia edilmiştir. Kur'an'ın ifadesiyle bu konuda Allah'a iftirada bulunulmuş, yalan söylenmiştir. ${ }^{26} \mathrm{Bu}$ bağlamda örneğin Araplar tarafından Allah adına birtakım şeylerin haram ya da helal olduğu ileri sürülmekte ve Bahîre, Sâibe, Vasîle ve Hâm ${ }^{27}$ gibi adetler üretilmektedir. Yine on-

26 “Artık, Allah'a karşı yalan uydurandan veya O'nun âyetlerini yalanlayandan daha zâlim kimdir? Şüphe yok ki (böyle) suçlular asla kurtuluşa ermezler. Allah'1 bırakıp, kendilerine ne zarar, ne de fayda verebilecek şeylere tapıyorlar ve "İşte bunlar Allah katında bizim şefaatçılarımızdır" diyorlar. De ki: "Siz, Allah'a göklerde ve yerde onun bilmediği bir şeyi mi haber veriyorsunuz!? O, onların ortak koştukları şeylerden uzaktır, yücedir." Yunus 17-18.

"Kim Allah'a karşı yalan uydurandan daha zalimdir? İşte bunlar, Rablerine arz edilecekler ve şâhitler de, "Rablerine karşı yalan söyleyenler işte bunlardır" diyeceklerdir. Biliniz ki, Allah'ın lâneti zalimler üzerinedir. Onlar (halkı) Allah yolundan alıkoyan ve onu eğri ve çelişkili göstermek isteyen kimselerdir. Hem de onlar ahireti inkâr edenlerin ta kendileridir." Hud 18-19.

27 “Allah Bahîre'den Sâibe'den Vasîle' den ve Hâm'dan hiç birini (meşru) kılmamıştır. Ancak inkâr edenler, Allah'a karşı yalan düzüp uyduruyorlar. Onların çoğu akıl erdirmez." Maide 103. Ayrica bkn. En'am 136-139. 
lar babalarının düzeni olarak adlandırdıkları geleneğin Allah tarafından tesis edildiğini iddia etmekte ve Allah'ın kitabına ve Resulünün davetine icabet etmeye çağrıldıklarında atalarının yolunun kendilerine yeter olduğunu söylemektedirler.

"Kötü bir şey yaptıkları zaman: "Babalarımızı onun üzerinde bulduk ve Allah onu bize emretti." dediler. De ki "Muhakkak ki; Allah, fahşâyı (kötülüğü, çirkinliği) emretmez. Allah'a bilmediğiniz bir şeyi mi söylüyorsunuz?" 28

"Onlara: "Allah'ın indirdiğine ve elçiye gelin" denildiğinde, "Atalarımızı üzerinde bulduğumuz şey bize yeter" derler. (Peki,) Ya ataları bir şey bilmiyor ve hidayete ermiyor idilerse?" 29

Cahiliye kültürünün karakteristik bir özelliği olan atalar kültüne dayalı olarak geleneğin kutsanması yalnızca geçmişte kalan bir husus değildir; günümüz toplumsal yapılarında da güçlü bir şekilde işlerliğini sürdürmektedir.

\section{Son Söz}

Cahiliye bundan on beş asır önce tarihin sayfalarında kalmış bir kültürel yap1, bir gelenek değildir. Tarih boyu hak ve hakikate dair doğru referansını kaybetmiş ya da bir tarafa bırakmış insanların içinde yaşadıkları evreni, var oluş nedenlerini ve sosyal yapıyı, hem kendi çıkar ve menfaatlerine hem de etraflarını çevreleyen güç ve çıkar odaklarına göre okuyup, inanç, düşünce ve yaşamlarını buna göre tesis etmeleridir. Cahiliye insanın Allah'ın otoritesine, gücüne ve iradesine sırtını dönmesi, dolayısıyla haddini aşması ve kendine zulmetmesi durumudur. Bu bağlamda cahiliye dün olduğu gibi bugün de büyük oranda insanların yaşamlarını kuşatmış durumdadır. İnsanların gerçek anlamda kurtuluşu etraflarını çevreleyen cahiliye geleneğini sorgulamaları, var oluşlarına dair gerçek amacın farkına varmaları ve kendilerini felaha kavuşturacak doğru yola girmeleriyle, yani Rableriyle tekrar buluşup barışarak onun mesajını bir yol rehberi edinmeleriyle mümkündür. Zira Rabbimizin dediği gibi

\footnotetext{
$28 \quad$ A'raf $28 .^{\prime}$

29 Mâide 104.
} 
Cahiliyenin Kültürel Kodları

"onlar ateşe çağırırlar, Allah ise izniyle, cennete ve bağışlanmaya çağırır. $\mathrm{O}$, insanlara ayetlerini açıklar ki, öğüt alıp düşünsünler." 30

\section{Kaynakça}

Joseph Wheless, Is it God's Word, New York: Kessinger, 2007.

Buhari, Sahih-i Buhari, Nikah 36.

Şinasi Gündüz, Anadolu'da Paganizm: Antik Dönemde Harran ve Urfa, Ankara: Ankara Okulu 2005.

Kur'an'ı Anlamak; İlahi Vahyin Tarihe Açılımı, İstanbul: Mana 2015.

Pavlus: Hıristiyanlı̆̆ın Mimarı, Ankara: Ankara Okulu 2001.

30 Bakara 221. 